\title{
Tand- en mondarts: tijd voor verandering
}

\begin{abstract}
Vanuit een lange klinische ervaring op het gebied van mondziekten en kaakchirurgie bepleit ik om de benaming tandarts te wijzigen in tand- en mondarts. Mijn belangrijkste en eigenlijk enige drijfveer voor dit voorstel is het gegeven dat met deze benaming meer duidelijkheid ontstaat bij het grote publiek over het werkterrein van de huidige tandarts. Thans wenden
\end{abstract} veel patiënten met mondklachten die niet direct aan het gebit gerelateerd lijken te zijn, zich als eerste tot hun huisarts. Soms blijken deze patiënten geen eigen tandarts te hebben, maar er leeft bij velen ook de gedachte dat een tandarts niet is ingesteld op beoordeling van bijvoorbeeld een afwijking van de tong. Van leken mag in dit verband overigens niet worden verwacht dat zij weten dat huisartsen vrijwel niet geschoold zijn op het gebied van mondziekten.

In het verleden is wel eens voorgesteld om de benaming tandarts te vervangen door mondarts. Dat was wat mij betreft geen goed idee omdat daarmee de zorg voor het gebit niet meer zichtbaar zou zijn. Bovendien zou een dergelijke term destijds tot verwarring hebben geleid bij het publiek en ook bij de medische professie voor wat betreft het onderscheid tussen enerzijds een mondarts en anderzijds een kaakchirurg. Deze verwarring is inmiddels nauwelijks meer denkbaar door het gebruik van de term mondziekten-, kaak-en aangezichtschirurg, kortweg MKA-chirurg.

En nog iets: is tand- en mondarts wellicht een ongelukkige, lange benaming? Maar wat dan te denken van keel-, neus- en oorarts of maag-, darm- en leverarts?

Moet nu de aanduiding tandarts overal worden vervangen door tand- en mondarts? Dat lijkt mij niet nodig. Laat bij voorbeeld de aanduiding tandarts-parodontoloog ongemoeid; dat geldt ook voor de tandarts-gnatholoog, de tandarts-implantoloog en de tandarts-endodontoloog. Bij voornoemde benamingen is immers duidelijk om welk specifiek aandachtsgebied het gaat en zou de toevoeging mondarts alleen maar gekunsteld aandoen. Maar is het niet logisch om te spreken van een kindertand- en mondarts? En hoe zit het met mondzorgkundigen en mondhygiënisten? Dan maar consequent aanpassen in tand- en mondzorgkundige, respectievelijk tand- en mondhygiënist? De noodzaak voor een dergelijke aanpassing lijkt te ontbreken, aangezien het werkterrein van deze beroepsgroep voldoende duidelijk is bij het grote publiek. Hoewel? Er zijn op dit gebied thans wel de nodige politieke ontwikkelingen gaande.

Over de gewenste titels van tandheelkundige tijdschriften is natuurlijk ook discussie mogelijk. Wordt het Tand- en Mondartspraktijk? Ja, even wennen. Dat geldt ook voor het Nederlands Tand-en Mondartsenblad en het Nederlands Tijdschrift voor Tand-en Mondartsen. Nadrukkelijk stel ik hier voor om niet te spreken over Nederlands Tijdschrift voor Tand- en Mondheelkunde aangezien er dan toch verwarring zou kunnen optreden ten opzichte van het werkterrein van de MKA-chirurg. Om dezelfde reden lijkt het niet zonder meer opportuun om de faculteitsaanduiding Tandheelkunde te wijzigen in Tand-en mondheelkunde.

Wat een gedoe! Toch maar eens goed over nadenken ondanks alle administratieve rompslomp, inclusief statutenwijzigingen. Is 2020 een realistische datum?

Isaäc van der Waal
Prof. dr. Isaäc van der Waal is als hoogleraar Orale Pathologie verbonden geweest aan VUmc en ACTA. Hij heeft speciale expertise op het gebied van mond- en kaakziekten, zowel klinisch als histopathologisch. 